\title{
Oor die verhouding tussen woordeboekstrukture, woordeboek- inhoud en leksikografiese funksies
}

Rufus H. Gouws, Departement Afrikaans en Nederlands, Universiteit van Stellenbosch, Stellenbosch, Republiek van Suid-Afrika (rhg@sun.ac.za)

Opsomming: Navorsing op die gebied van die metaleksikografie het oor die laaste paar dekades 'n betekenisvolle fokusverbreding ondergaan. Die aanvanklike fokus was veral op die woordeboekinhoud. Mettertyd het die fokus verskillende woordeboekstrukture ingesluit en tans val leksikografiese funksies binne die bestek van metaleksikografiese navorsing. Al drie hierdie komponente van die leksikografie is ter sake vir die beplanning en samestelling van gebruikergedrewe woordeboeke. In hierdie artikel word aangetoon dat die vertrekpunt in die beplanning van ' $n$ nuwe woordeboek nie in die eerste plek 'n bestaande woordeboek moet wees nie. Die teikengebruiker moet die vertrekpunt van die hele leksikografiese proses uitmaak. Dit moet lei tot die vasstelling van leksikografiese funksies, die keuse van leksikografiese data en die bepaling van die relevante woordeboekstrukture. Hierdie strukture moet die data op so 'n manier aanbied dat die gebruiker in staat is om 'n optimale onttrekking van inligting te bereik. Terselfdertyd moet die leksikografiese funksies van die woordeboek probleemloos vervul kan word.

Sleutelwoorde: DATAVERSPREIDINGSTRUKTUUR, GEBRUIKERGEDREWE BENADERING, GEBRUIKERSITUASIE, GEBRUIKERSPERSPEKTIEF, GEBRUIKSITUASIE, KENNISGERIGTE FUNKSIES, KOMMUNIKASIEGERIGTE FUNKSIES, LEKSIKOGRAAF, LEKSIKOGRAFIESE DATA, LEKSIKOGRAFIESE FUNKSIES, LEKSIKOGRAFIESE PROSES, TEKSPRODUKSIE, TEKSRESEPSIE, TOEGANGSTRUKTUUR, WOORDEBOEKBEPLANNING, WOORDEBOEKGEBRUIKER, WOORDEBOEKINHOUD, WOORDEBOEKSTRUKTURE

\footnotetext{
Abstract: About the Relationship between Dictionary Structures, Dictionary Contents and Lexicographic Functions. Over the last few decades, research in the field of metalexicography has undergone a significant broadening of scope. The original focus had chiefly been on the contents of dictionaries. In the course of time, the focus also included different dictionary structures and the scope of current metalexicographic research accommodates lexicographic functions. These three components of lexicography are all relevant in the planning and compilation of user-driven dictionaries. In this article, it is shown that the point of departure in the planning of a new dictionary should in the first instance not be an existing dictionary. The target user should constitute the point of departure of the whole lexicographic process. This should lead to the identification of lexicographic functions, the choice of lexicographic data and the selection of relevant dictionary structures. These structures should present the data in such a way that the user is able to achieve an optimal retrieval of information. At the same time the lexicographic functions of the dictionary should be accomplished in an unproblematic way.
} 
Keywords: ACCESS STRUCTURE, COMMUNICATION-ORIENTED FUNCTIONS, DATA DISTRIBUTION STRUCTURE, DICTIONARY PLANNING, DICTIONARY STRUCTURES, DICTIONARY USER, KNOWLEDGE-ORIENTED FUNCTIONS, LEXICOGRAPHER, LEXICOGRAPHIC DATA, LEXICOGRAPHIC FUNCTIONS, LEXICOGRAPHIC PROCESS, TEXT PRODUCTION, TEXT RECEPTION, USAGE SITUATION, USER-DRIVEN APPROACH, USER-PERSPECTIVE, USER SITUATION

\section{Inleidend}

'n Oorsig van die ontwikkeling van die teoretiese leksikografie bied 'n duidelike beeld van die verskuiwing in die relatiewe posisionering van die leksikografie as vakgebied. Tydens die vroeë ontwikkelingsjare van die metaleksikografie, veral in die tydperk kort na die verskyning van Ladislav Zgusta se baanbrekende werk Manual of Lexicography (1971), was dit een van die groot deurbrake dat die teoretiese leksikografie die vroeëre skeptisisme van talle linguiste kon afskud om 'n plek te verdien as 'n wesenlike komponent van die taalkunde. Die teoretiese leksikografie, onder meer ook die benadering in Zgusta (1971), was veral gerig op die taalkundige inhoud van woordeboeke en met dié navorsings- en studiefokus het die posisie van die teoretiese leksikografie algaande verbeter tot 'n volwaardige subdissipline van die taalkunde (vgl. in hierdie verband Gouws 2004).

Die taalkunde het taal en die wetenskaplike beskouing van taal as studieterrein. Die teoretiese leksikografie het woordeboeke en 'n wetenskaplike beskouing van woordeboeke as studieveld en in die laaste dekades het hierdie beskouing van woordeboeke in so 'n mate ontwikkel dat dit tans in die leksikografie om veel meer as net die taalkundige aanbod in woordeboeke gaan. In hierdie verband is die navorsingsaanslag van teoretiese leksikograwe aangepas om naas die taalkundige inhoud ook die struktuur en in die onlangse jare ook die funksies van woordeboeke in te sluit. As gevolg van hierdie fokusverbreding wat tot meer as net die taalkundige beskouing van woordeboeke gelei het, het die siening onder teoretiese leksikograwe posgevat dat die leksikografie nie meer 'n subdissipline van die taalkunde is nie, maar dat dit tot 'n volwaardige en selfstandige dissipline ontwikkel het (vgl. in hierdie verband Hartmann en James 1998, Wiegand 1998 en Tarp 2000). Hierdie verandering het gelei tot ' $n$ wesenlike behoefte aan navorsing oor die rol en waarde van woordeboekstrukture en leksikografiese funksies asook hulle onderlinge verhouding en wisselwerking met die inhoud van woordeboeke, woordeboektipologie en die belang van die gebruikersperspektief. Dit is van dié aspekte wat in hierdie artikel ter sprake kom. In hierdie verband is dit egter ook ter sake om aandag te gee aan die leksikograaf en aan die gebruiker- en gebruiksituasie van 'n bepaalde woordeboek. 


\section{Die rol van die leksikograaf}

'n Opvallende kenmerk van die moderne leksikografie is die aktiewe wisselwerking tussen teorie en praktyk. Gelukkig is baie praktiserende leksikograwe daarvan bewus dat hulle die gehalte van hulle woordeboeke kan verbeter indien die woordeboeke 'n stewige teoretiese basis het. Gelukkig is baie teoretiese leksikograwe daarvan bewus dat die werklike sukses van hulle navorsingsopdrag ' $n$ werklikheid word wanneer dit neerslag vind in die leksikografiepraktyk en dat hulle teorieë op so 'n manier geformuleer moet word dat dit interpreteerbaar is in terme van die eise van die praktyk. 'n Leksikografiese proses is gerig op die uiteindelike produksie van woordeboeke en vir hierdie proses om suksesvol te verloop, mag die rol van die leksikograaf wat die betrokke woordeboek saamstel, nooit onderskat word nie.

Leksikograwe kan in ten minste vier groepe verdeel word: dié wat slegs by die leksikografiepraktyk betrokke is, sonder enige kennis van of belangstelling in die teoretiese leksikografie; dié wat veral by die leksikografiepraktyk betrokke is, maar met 'n kennis van en belangstelling in die teoretiese leksikografie; dié leksikograwe wat veral betrokke is by die teoretiese leksikografie, maar met ' $n$ belangstelling in en ervaring van die praktiese leksikografie, en, laastens, dié leksikograwe wat slegs betrokke is by die teoretiese leksikografie, sonder enige belangstelling in of ervaring van die leksikografiepraktyk. Die sukses van leksikografiese werk op sowel die praktiese as die teoretiese vlak is dikwels afhanklik van die relatiewe posisie van die leksikograaf binne die genoemde vierdeling. Die twee middelste groepe wat die wisselwerking tussen teorie en praktyk verteenwoordig, vorm dikwels die basis vir suksesvolle leksikografiese prosesse. Die twee groepe op die eindpunte van die vierdeling het ook 'n rol om te speel, maar hulle werk het dikwels bykomende ondersteuning nodig om sukses te verseker. 'n Leksikograaf wat geen begrip van die leksikografiese praktyk het nie en wat slegs op 'n abstrakte vlak werk se navorsingsbevindinge het dikwels weinig toepassingswaarde. In so 'n geval gaan dit te maklik slegs om teorie ter wille van die teorie. Die ander uiterste is dat praktiserende leksikograwe te min teoretiese kennis het om suksesvol deel te hê aan die beplanning van innoverende woordeboekprojekte. Hulle kan 'n woordeboek volgens 'n voorgeskrewe woordeboekplan saamstel en kan selfs help met die ontwerp van 'n nuwe leksikografiese proses, maar dan moet daar meestal staatgemaak word op die voorbeeld van reeds bestaande projekte en woordeboeke. Hulle kan vanaf 'n bestaande model na die gebruiker toe werk, maar kan nie op grond van die gebruiker se eiesoortige behoeftes 'n nuwe en gepaste woordeboekkonseptualiseringsplan ontwerp nie. Die uiteindelike sukses van 'n woordeboek word medebepaal deur die kennis en ervaring van die leksikograaf, die leksikograaf se vertroudheid met sowel die leksikografieteorie as die leksikografiepraktyk en 'n erkenning van die noodsaaklikheid van 'n gebruikersgedrewe benadering in die beplanning en samestelling van die woordeboek. Die gebruikersgedrewe benadering vereis ook ' $n$ insig in die tipiese gebruiker- en gebruiksituasie. 


\section{Gebruiker- en gebruiksituasies}

Wanneer daar gekyk word na 'n woordeboek-spesifieke leksikografiese proses beperk 'n mens te maklik die omvang van dié proses deur veral of selfs uitsluitlik te fokus op die woordeboeksamestellingsfase van die proses. Die leksikografiese proses sluit egter veel meer as net die woordeboeksamestelling in, want die skryf van die woordeboek word voorafgegaan en gevolg deur 'n reeks fases, onder meer ' $n$ fase waartydens indringend aandag gegee word aan die tipiese situasie waarbinne die betrokke woordeboek gebruik gaan word. Tydens die beplanningsfase van ' $n$ woordeboek is dit belangrik om te weet wie die potensiële gebruikers van die woordeboek sal wees, maar ook wat die tipiese gebruiker- en gebruiksituasie sal wees, wat die probleme van die teikengebruikers in die bepaalde gebruiksituasies is, watter data aangebied word en ook hoe dit aangebied moet word om die gebruiker optimaal ter wille te kan wees. 'n Vertroudheid met die gebruiker, die gebruiker- en gebruiksituasie is voorvereistes vir besluite oor die relevante leksikografiese funksies van 'n gegewe woordeboek. Hierdie kennis van die gebruiker en die gebruiker- en gebruiksituasie vorm die basis vir die grondlegging van 'n teoretiese benadering waar leksikografiese funksies 'n wesenlike rol speel.

Die hoofmikpunt van die leksikografie as 'n wetenskaplike praktyk is die totstandbrenging van 'n leksikografiese proses wat gerig is op die produksie van woordeboeke wat die teikengebruikers se behoeftes bevredig. Woordeboeke word saamgestel om as praktiese gebruiksinstrumente te dien en hulle sukses of mislukking word eers bepaal wanneer die werklike gebruikers hierdie woordeboeke in die werklike gebruiksituasie benut. Die beskikbaarstelling van 'n woordeboek aktiveer 'n volgende fase in die leksikografiese proses, te wete die kulturele praktyk van woordeboekgebruik (vgl. Wiegand 1989: 251). Om die suksesvolle gebruik van 'n woordeboek te verseker, moet die woordeboek op so 'n manier beplan word dat daar voldoende voorsiening gemaak word vir die eise van die tipiese situasie waarin die woordeboek gebruik gaan word.

In sowel die teoretiese as die praktiese leksikografie is daar tot dusver veels te min aandag gegee aan 'n ondubbelsinnige vasstelling van die tipiese gebruiker- en gebruiksituasies van woordeboeke. 'n Leksikografiese benadering waar leksikografiese funksies 'n wesenlike rol speel, word daardeur gekenmerk dat die woordeboek nie net op 'n spesifieke gebruiker gerig is nie maar ook op 'n spesifieke gebruiksituasie. Die gebruikersituasie het in die metaleksikografiese literatuur meer aandag gekry as die gebruiksituasie. Tarp (2004: 232) dui byvoorbeeld aan dat die volgende gebruikersituasies ter sake is in aanleerderleksikografie: teksresepsie in die vreemde taal, teksproduksie in die vreemde taal, doelgerigte studie van die grammatikale stelsel van die vreemde taal en 'n doelgerigte studie van die leksikale stelsel van die vreemde taal.

Die gebruiksituasie waaraan nog min aandag gegee is, het onder meer te make met die fisiese omgewing waarin en praktiese omstandighede waaronder 
'n woordeboek gebruik moet word. Hierdie faktore behoort 'n invloed te hê op verskillende aspekte van die beplanning van woordeboeke. Die fisiese omgewing waarbinne 'n woordeboek gebruik word, kan byvoorbeeld 'n regstreekse invloed hê op die suksesvolle onttrekking van inligting. Die gebruikers van byvoorbeeld ' $n$ standaard verklarende woordeboek vir moedertaalsprekers van Britse Engels in Engeland sal waarskynlik die woordeboek onder ander omstandighede gebruik as byvoorbeeld 'n laerskoolleerder van Engels as addisionele taal met Tswana as moedertaal wat in 'n plattelandse Suid-Afrikaanse omgewing woon. Die gebruiker van die Britse woordeboek raadpleeg waarskynlik die woordeboek in 'n biblioteek, tuis of in 'n kantoor binne ' $n$ omgewing wat ondersteun word deur 'n goed gevestigde woordeboekkultuur. Daarteenoor kan dit gebeur dat die Tswanaleerder nie op dieselfde mate van woordeboekkultuur kan staatmaak nie en in 'n omgewing verkeer wat veel minder geskik is vir suksesvolle woordeboekgebruik as dié van die Britse gebruiker. By die beplanning van hierdie woordeboek vir die Tswanaleerder moet leksikograwe voorsiening maak vir 'n verskeidenheid gunstige, maar ook minder gunstige gebruiksituasies. Die leksikograaf moet besef dat die woordeboek dalk gebruik word in 'n klaskamer met of sonder die hulp van 'n onderwyser, of tuis met of sonder die ondersteuning van ouers. "Tuis" verwys ook nie noodwendig na 'n goed toegeruste studeerkamer nie. Hierdie gebruiksituasie mag onder 'n boom of in 'n plakkershuis sonder elektrisiteit wees. Waar ' $n$ gebruiksituasie voorsien word met min of geen ondersteuning van onderwysers of ouers nie en veral waar die fisiese omgewing ongunstig is vir maklik lees, bv. as gevolg van swak lig weens gebrek aan elektrisiteit, moet die data wat in die woordeboek verstrek word en die manier waarop dit aangebied word, aangepas word om die gebruiker so goed as moontlik te help. Om seker te maak dat die werklike doel van 'n woordeboek bereik word, is dit noodsaaklik dat daar aan 'n wye spektrum aangeleenthede aandag gegee word in die beplanningsfase van die woordeboek. 'n Woordeboek wat saamgestel word vir gebruikers wat nog nie vlot lesers is nie, moet byvoorbeeld liefs 'n groter lettertipe gebruik as 'n woordeboek wat op vlot lesers gerig is - op 'n soortgelyke manier as in handboeke vir die vroeë grade op skool. Ook oor die aanbod van data en die mate van teksverdigting moet met inagneming van die gebruiker en gebruiksituasie besluit word. Woordeboekuitleg is nie 'n kosmetiese deel van die publikasie van woordeboeke of 'n blote kwessie van die druk van ' $n$ boek nie, maar 'n wesenlike komponent van die leksikografiese proses wat veel daartoe kan bydra dat die werklike doel van 'n woordeboek bereik word, deurdat dit die sukseskoers van die woordeboeknaslaanpogings kan verhoog. Die uitleg van 'n woordeboek mag gevolglik nie slegs aan die uitgewer oorgelaat word nie, want dit is 'n leksikografiese verantwoordelikheid wat verrig moet word as deel van 'n gebruikersgerigte benadering en as 'n reaksie op die spesifieke behoeftes en naslaanvaardighede van die teikengebruikers (vgl. Swanepoel 2001). Die spesifieke gebruiker- en gebruiksituasie van 'n woordeboek kan bepalend wees vir die uitleg daarvan. 
In die metaleksikografie benadruk 'n fokus op leksikografiese funksies die gebruikergedrewe benadering, insluitend die gebruiksituasie, baie sterk. Die gebruiksituasie moet op 'n ondubbelsinnige manier omskryf word en sluit veel meer besonderhede in as wat dikwels deur leksikograwe besef of erken word.

\section{4. 'n Tradisionele vertrekpunt in die beplanning van woordeboeke}

Die sukses van 'n leksikografiese proses is onder meer afhanklik van die regte vertrekpunt vir die beplanning van die woordeboek. Die eiesoortige aard van verskillende teikengebruikersgroepe is sodanig dat hierdie vertrekpunt, ook met betrekking tot die ontwerp en formulering van 'n woordeboekkonseptualiseringsplan, liefs nie te sterk op bestaande woordeboeke moet steun nie.

In 'n gebruikergedrewe leksikografiese proses waar die beplanning van 'n woordeboek bepaal word deur die leksikografiese funksies sal die vertrekpunt vir die formulering van die woordeboekkonseptualiseringsplan nie bestaande woordeboeke wees nie - alhoewel bestaande woordeboeke en hulle benutting in werklike gebruiksituasies wel 'n ondergeskikte rol mag speel. Dolezal (1986: 47) verwys na die vroeë Engelse leksikografie as 'n reeks geredigeerde en hersiene tekste. Vir baie jare was daar in die Engelse leksikografie min tekens van werklike vernuwing waar 'n nuwe woordeboek met 'n aanbod of benadering gekom het wat grootliks afwyk van dié van bestaande woordeboeke, en 'n bydrae lewer wat gerig is op die veranderde behoeftes van die teikengebruikers. Leksikograwe het te dikwels in die beplanning van hulle woordeboeke onkrities staat gemaak op reeds verskene woordeboeke in stede daarvan om innoverend te werk te gaan en 'n woordeboek te beplan wat nie op ander woordeboeke gebaseer is nie, maar regstreeks volg uit die behoeftes van die teikengebruikers. Die beplanningsfase van 'n leksikografiese proses moet nie primêr 'n herhaling van dié van 'n bestaande woordeboek of 'n geringe aanpassing daarvan wees nie. So 'n proses wat bloot gebaseer is op ' $n$ ander woordeboek vir die lewering van 'n model vir 'n nuwe woordeboek, word in figuur 1 voorgestel:

\section{Figuur 1}

Bestaande woordeboek(e) - Beplanningsfase $>$ Nuwe woordeboek

Hierdie tipe benadering mag tot die produksie van 'n goeie woordeboek lei indien 'n goeie woordeboek as vertrekpunt gebruik is, maar dit beteken nie noodwendig dat die nuwe woordeboek op 'n gepaste manier vir die spesifieke teikengebruikersgroep saamgestel is nie; veral nie wanneer die leksikografiese funksies en teikengebruikers van die twee woordeboeke nie ooreenstem nie. Vir die bes moontlike nuwe woordeboekprojekte is dit wel nuttig om vertroud te wees met bestaande woordeboeke, maar sulke woordeboeke behoort nie 'n beslissende rol in die beplanning te speel nie. Die geïdentifiseerde teikengebruikers, hulle behoeftes en naslaanvaardighede en die tipiese gebruiksituasies van die beplande woordeboek behoort die beplanning te rig. 


\section{Die gebruiker as vertrekpunt}

Wanneer die gebruiker die vertrekpunt van 'n nuwe woordeboek se beplanning is, skep dit die ideale situasie vir die totstandbrenging van 'n bevredigende verhouding tussen leksikografiese funksies, woordeboekstrukture en woordeboekinhoud. Om dit moontlik te maak, is dit belangrik dat die leksikograaf in 'n heel vroeë fase van die woordeboekbeplanning die teikengebruiker van die beplande woordeboek ondubbelsinnig moet identifiseer en uitsluitsel moet kry oor die behoeftes en naslaanvaardighede van hierdie teikengebruiker. Vervolgens moet vasgestel word hoe die beplande woordeboek in die behoeftes van die teikengebruiker kan voorsien en wat die woordeboekgebruiker met die woordeboek moet kan verrig. 'n Antwoord hierop lei tot die vasstelling van die leksikografiese funksies. Die vasstelling van die leksikografiese funksies moet gesien word as grondliggend aan die vroeë beplanning van die woordeboek en verteenwoordigend van dit waarmee die woordeboek as praktiese instrument die teikengebruiker help. Die gebruiker staan sentraal in die vasstelling van die betrokke funksies.

\section{Leksikografiese funksies, woordeboekstrukture en leksikografiese data}

Om die gebruiker en die gebruiker se behoeftes as vertrekpunt te hê in die beplanning van 'n nuwe woordeboek noop die leksikograaf om te besin oor die noodsaaklikheid van leksikografiese funksies en die tipe woordeboekstrukture, en om die woordeboekplan dienooreenkomstig op te stel. 'n Leksikografiese funksie (vgl. Tarp 2000: 196) verteenwoordig die hulp wat 'n woordeboek verskaf aan 'n spesifieke gebruiker ter bevrediging van die behoeftes van daardie gebruiker in 'n spesifieke gebruikersituasie. Omdat elke woordeboek op spesifieke behoeftes van spesifieke teikengebruikers gerig is, is dit moeilik om ' $n$ bestaande woordeboek te vind met 'n identiese teikengebruikergroep en identiese behoeftes wat presies ooreenstem met die omstandighede van die nuwe woordeboek. Die moderne metaleksikografie gaan van die standpunt uit dat geen enkele woordeboek alles vir almal kan wees nie. Spesifieke woordeboeke is op spesifieke gebruikers, behoeftes, gebruiker- en gebruiksituasies en leksikografiese funksies gerig. Daarom behoort elke woordeboek uniek beplan te word. In hierdie verband speel leksikografiese funksies 'n beslissende rol.

Binne 'n funksiegedrewe benadering word 'n onderskeid gemaak tussen twee hooffunksietipes, te wete kennisgerigte en kommunikasiegerigte funksies (vgl. Tarp 2000, Bergenholtz en Tarp 2002 en Tarp en Gouws 2004). Kennisgerigte funksies help gebruikers met algemene kulturele en ensiklopediese data, spesiale data oor die onderwerpsveld en data oor die taal. Kommunikasiegerigte funksies help met die oplossing van probleme met betrekking tot teksproduksie in die moedertaal of vreemde taal, teksresepsie in die moedertaal of vreemde taal en die vertaling van tekste vanaf die moeder- na die vreemde taal en omgekeerd. 
Die leksikografiepraktyk het in 'n preteoretiese era ontwikkel en in die verlede, selfs die heel onlangse verlede, is baie woordeboeke beplan sonder enige aanduiding van hulle leksikografiese funksies. Desondanks het die dataaanbod in woordeboeke dikwels daartoe gelei dat sekere funksies wel vervul is, maar nie op 'n beplande, gestruktureerde of voorspelbare manier nie. Vandag word 'n vroeë vasstelling van die leksikografiese funksies as 'n verpligte komponent van die beplanningsfase van enige woordeboek-spesifieke leksikografiese proses gesien en woordeboekopstellers moet bewus wees van hierdie belangrike opdrag. In 'n ideaal-tipiese leksikografiese wêreld sou elke woordeboek slegs 'n enkele leksikografiese funksie vervul. Om al die onderskeie funksies in verskillende monofunksionele woordeboeke gerealiseer te kry, sou tot die samestelling van vier of selfs agt woordeboeke van dieselfde tipologiese kategorie gelei het (vgl. in hierdie verband Ščerba 1940, Hausmann 1977 en Kromann et al. 1984). Om praktiese en ekonomiese redes is dit nie moontlik nie en gevolglik word daar vandag dikwels meerfunksionele woordeboeke saamgestel (vgl. bv. Wiegand 1996 se pleidooi vir 'n enkele polifunksionele woordeboek). So 'n woordeboek hoef nie gelyke aandag te gee aan al die genoemde of ook ander leksikografiese funksies nie, maar die leksikograaf moet al daardie funksies wat in die woordeboek aan bod kom, op 'n ondubbelsinnige manier vasstel, omskryf en konsekwent en sistematies toepas. Nadat die funksies vasgestel is, is dit belangrik om te besluit hoe die funksies ten beste in die woordeboek aan die orde kom. In hierdie verband is dit noodsaaklik om noukeurig te let op die verskillende woordeboekstrukture, die datakeuse en die data-aanbod om die uitvoering van die betrokke leksikografiese funksies te verseker. Dit voorvereis weer eens 'n kennis van die gebruikerprofiel en die woordeboekgebruiksituasie.

In die metaleksikografie moet daar steeds daarteen gewaak word om nie een navorsingskomponent so te isoleer dat dit nie meer as deel van die groter navorsingsgebied van die teoretiese leksikografie gesien word nie. Of dit oor byvoorbeeld woordeboekstruktuur, leksikografiese funksies of die inhoud van woordeboeke gaan, bly dit noodsaaklik om steeds die onderlinge verhouding tussen die verskillende komponente in gedagte te hou en nie een komponent te verabsoluteer as sou dit die kernaspek van die leksikografieteorie verteenwoordig nie. 'n Benadering wat net aandag gee aan een van die komponente, bv. woordeboekstrukture of leksikografiese funksies, kan maklik die balans wat binne 'n algemene leksikografieteorie bestaan, versteur en daardeur die ontwikkeling van 'n model vir 'n gebruikersgerigte woordeboek benadeel. Dit is belangrik dat navorsing gedoen word oor die verskillende individuele komponente van die leksikografieteorie, maar die relatiewe verband met die algemene teorie en die posisionering met betrekking tot die ander komponente moet steeds voor oë gehou word.

Die belang van woordeboekstrukture in die studie van die leksikografie mag nooit ontken word nie. Dit is juis een van die fokuspunte in die verskuiwing van die leksikografie vanaf 'n subdissipline van die taalkunde tot 'n volwaardige en selfstandige dissipline in eie reg (vgl. Gouws 2004). Een van die 
opwindende benaderings in die metaleksikografie van die afgelope twintig jaar is die vasstelling en uitvoerige beskrywing van 'n groot verskeidenheid woordeboekstrukture (vgl. in hierdie verband veral die werk van Wiegand, bv. Wiegand 1989a, 1989b, 1989c, Hausmann en Wiegand 1989 en Gouws en Prinsloo 2005).

Vir die produksie van suksesvolle woordeboeke, die ontwikkeling van 'n verbeterde leksikografiese praktyk en die aktivering van suksesvolle woordeboekgebruik, is die regte verhouding tussen woordeboekstrukture en leksikografiese funksies van die uiterste belang. Waar navorsing oor veral woordeboekstrukure in die laat tagtiger- en negentigerjare van die vorige eeu aan die orde was, is hierdie navorsing in die laaste dekade aangevul deur navorsing gerig op die rol van leksikografiese funksies. Sommige metaleksikograwe (vgl. Bergenholtz en Tarp 2002), gaan so ver om hulle navorsing te rig op die ontwikkeling van 'n teorie van leksikografiese funksies wat vir hulle die basis van die teoretiese leksikografie vorm. Die gevaar verbonde aan so ' $n$ benadering is die oorbeklemtoning van leksikografiese funksies ten koste van woordeboekstrukture.

Eerder as die verheffing van een komponent tot 'n dominante faktor behoort daar gelet te word op die aktiewe wisselwerking tussen funksies en strukture. 'n Leksikografieteorie behoort nie verskraal te word tot 'n teorie van leksikografiese funksies of ' $n$ teorie van woordeboekstrukture nie. Binne 'n algemene leksikografieteorie moet daar voldoende ruimte geskep word vir sowel leksikografiese funksies as woordeboekstrukture en vir 'n bepaalde verhouding tussen hierdie twee komponente van die teorie.

Tydens die ontwerp van 'n leksikografiese proses moet leksikograwe daarvan bewus bly dat die woordeboekkonseptualiseringsplan sentraal staan in die vroeë stadiums van die beplanningsfase. Die wesenlike kenmerke van enige woordeboek sluit die leksikografiese funksies, die woordeboekstrukture asook die leksikografiese data in (vgl. in hierdie verband Nielsen 2003). 'n Woordeboek bevat leksikografiese data, vertoon bepaalde strukture en moet sekere spesifieke funksies verrig. Die woordeboekkonseptualiseringsplan vereis 'n kombinasie van hierdie drie kenmerke om die sukses van die betrokke woordeboek te verseker. Tradisionele benaderings in die beplanning van woordeboeke het veral sterk gefokus op die inhoud, dit is die data wat in die woordeboeke aangebied moet word. Die aanbod van data in bestaande woordeboeke het meestal as model gedien. Aanvanklik in 'n mindere, maar later in 'n toenemende mate, is daar aandag gegee aan bepaalde strukture van woordeboeke, maar nogmaals is daar veral gewerk met die voorbeeld van bestaande woordeboeke. Ondanks die werk van vroeë metaleksikograwe soos Ščerba (vgl. Ščerba 1940), is daar oor die algemeen baie lank min aandag aan die rol en waarde van leksikografiese funksies gegee. Waar leksikografiese funksies wel ter sprake gekom het, was dit dikwels toevallig en selde die gevolg van 'n beplanningsproses.

Een van die eerste kwessies ter sake vir die leksikograaf in die formulering van 'n woordeboekkonseptualiseringsplan raak die leksikografiese funksies van 
die voorgenome woordeboek. Dié funksies word nie arbitrêr gekies nie, maar word deur die gebruikersprofiel bepaal en help die gebruiker om daardie probleme op te los wat aanleiding gegee het tot 'n bepaalde woordeboeknaslaanhandeling. Om te verseker dat bepaalde funksies wel in 'n woordeboek geld, is dit belangrik om hulle vooraf te identifiseer en die beplanning en keuse van woordeboekstrukture en leksikografiese data dienooreenkomstig te doen. Sodra die funksies van 'n woordeboek vasgestel is, kan die data en die strukture gekies word wat nodig is om die funksies te laat realiseer. So 'n benadering werk met die funksies as vertrekpunt in die beplanning van 'n woordeboek en sien die verwesenliking van die funksies as 'n produk van, onder meer, die leksikografiese data en die woordeboekstrukture. Die leksikografiese strukture speel 'n belangrike rol, want die data-items mag nie op 'n arbitrêre manier georden word nie, maar wel volgens die kriteria wat ontwikkel is om die verwerkliking van die funksies en die werklike doel van die woordeboek te verseker. Waar woordeboekbeplanning op hierdie manier gedoen word, dien 'n bestaande woordeboek nie as vertrekpunt nie, maar die gebruikersgedrewe benadering neem leksikografiese funksies en dus die gebruiker as vertrekpunt. Nogmaals is ondersteuning vanuit die teoretiese leksikografie nodig, soos blyk uit figuur 2:

\section{Figuur 2}

\begin{tabular}{|c|}
\hline $\begin{array}{c}\text { Vertrekpunt } \\
\text { Identifisering van die } \\
\text { potensiële woordeboekgebruiker } \\
\text { gebruikersbehoeftes } \\
\text { gebruikersituasie } \\
\text { gebruiksituasie }\end{array}$ \\
\hline $\boldsymbol{\nabla}$ \\
\hline Vasstelling van die relevante leksikografiese funksies \\
\hline $\boldsymbol{\nabla}$ \\
\hline Benutting van die leksikografieteorie \\
\hline $\boldsymbol{\nabla}$ \\
\hline Keuse van gepaste data-items \\
\hline
\end{tabular}


Toepassing van die dataverspreidingstruktuur en die aanbieding van data-items

Totstandbrenging van 'n nuwe woordeboek

'n Sodanige beplanning van 'n woordeboek vereis 'n doeltreffende en behoorlike kennis en benutting van woordeboekstrukture. Een van die uitdagings in hierdie verband aan die leksikograwe is die keuse van strukture wat relevant is vir die betrokke woordeboek. 'n Funksiegedrewe keuse van woordeboekstrukture het implikasies vir die tipe struktuur, maar ook vir die manier waarop die struktuur benut word. Nogmaals moet die gebruikersperspektief deurslaggewend wees in die besluit.

\section{Die keuse van woordeboekstrukture}

Wanneer die teikengebruiker, eerder as 'n bestaande woordeboek, die motivering vir die beplanning en samestelling van 'n nuwe woordeboek is, lê een van die uitdagings van die leksikograaf daarin om van die geïdentifiseerde leksikografiese funksies te beweeg na 'n vasstelling van die relevante datatipes, die keuse van data-items en van tersaaklike woordeboekstrukture om die data te kan akkommodeer en leksikografies te kan vergestalt (vgl. weer eens figuur 2). Hier is die wisselwerking tussen leksikografieteorie en -praktyk akuut ter sake. Praktiserende leksikograwe moet vertroud wees met ' $n$ verskeidenheid aspekte van die teoretiese leksikografie, maar dit is ewe belangrik dat teoretiese leksikograwe bewus moet wees van die eiesoortige aard van die uitdagings van die leksikografiepraktyk om hulle navorsing te kan rig op die komplekse probleme van die praktiserende leksikograaf. Die bevindinge van die navorsing van die teoretiese leksikografie moet in terme van die eise van die praktyk interpreteerbaar en toepasbaar wees. Navorsing oor woordeboekstrukture kan te maklik gesien word as 'n uiters abstrakte poging wat geïsoleerd staan van die leksikografiepraktyk. Woordeboekstrukture mag nooit beskou word as die uiteindelike doelwit van leksikografiese navorsing nie. Indien woordeboekstrukture en die navorsing daaroor van die praktyk geskei word, laat dit maklik daardie indruk ontstaan. Woordeboekstrukture moet steeds binne die breër leksikografiese konteks gesitueer word waar dit gesien word as 'n middel tot ' $n$ doel. Hierdie doel is om met die data te kombineer en 'n data-aanbod moontlik te maak wat die vervulling van die relevante leksikografiese funksies kan bewerkstellig. Om dit te verseker, is baie navorsing oor woordeboekstrukture nog nodig sodat werklike leksikograwe wat werklike woordeboeke vir werklike gebruikers saamstel, die werklike probleme die hoof kan bied.

In die beplanningsfase van die leksikografiese proses van enige nuwe woordeboek moet die leksikograwe daarvan bewus wees dat dit nie nodig is om 'n plek te vind vir elk van die talle strukture wat reeds in die metaleksikografiese literatuur geïdentifiseer is nie. Hier speel woordeboektipologie en lek- 
sikografiese funksies, en by implikasie dus ook die gebruikersperspektief, 'n bepalende rol. Slegs daardie strukture wat ter sake is vir die vervulling van die vasgestelde leksikografiese funksies van die betrokke woordeboeksoort binne die raamwerk van sy tipologiese kriteria, moet vir aanwending in die woordeboek oorweeg word. In hierdie verband het teoretiese leksikograwe die verantwoordelikheid om die praktiserende leksikograwe te help met die vasstelling van daardie strukture wat oorweeg moet word sodat 'n spesifieke funksie of funksies in 'n woordeboek vervul kan word. Sulke strukture mag nie 'n kosmetiese toevoeging tot die woordeboek wees nie, maar moet meehelp om die vervulling van die relevante leksikografiese funksies te bevredig.

In die studie van woordeboekstrukture kan daar onder meer 'n onderskeid gemaak word tussen kernstrukture (vgl. Mihindou in voorbereiding) en gidsstrukture (vgl. Louw 1997). Die kernstrukture is onder meer die dataverspreidingstruktuur, die makrostruktuur en die mikrostruktuur, en die gidsstrukture is die toegangstruktuur en die mediostruktuur. In die hieropvolgende afdeling word daar aan die hand van voorbeelde uit die leksikografiepraktyk gewys op maniere waarop van hierdie woordeboekstrukture aangewend word. Daar word ook verwys na implikasies daarvan vir die bereiking van bepaalde leksikografiese funksies.

\section{Van teorie na praktyk}

Met die gebruiker as vertrekpunt, bepaal die tipologiese kategorie van 'n woordeboek en die leksikografiese funksies watter soort strukture benut word om die woordeboekinhoud weer te gee sodat die vasgestelde leksikografiese funksies bereik kan word. In enige woordeboek is kernstrukture soos die dataverspreiding-, makro- en mikrostruktuur, asook die toegangstruktuur as een van die gidsstrukture, deurgaans ter sake. Die manier waarop hierdie strukture op 'n woordeboek-spesifieke manier aangewend word, is ter sake vir die sukses van die betrokke woordeboek. Vervolgens word daar gekyk na aspekte van woordeboekstrukture in Nuwe Woordeboek sonder Grense (voortaan NWSG) (vgl. ook Steyn en Gouws 2005).

NWSG is beplan as ' $n$ multifunksionele woordeboek met veral kommunikasiegerigte, maar ook kennisgerigte funksies. Die kommunikasiegerigte funksies sluit sowel teksproduksie as teksresepsie in. Hierdie woordeboek is saamgestel vir addisioneletaalleerders van Afrikaans in die senior primêre en junior sekondêre skoolfases. Dit is ' $n$ eentalige verklarende woordeboek met ' $n$ tweetalige dimensie, soos blyk uit die insluiting van 'n Engelse ekwivalent van die lemma in elke voorbeeldsin. Vergelyk die volgende artikel:

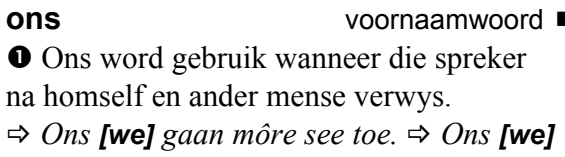


ry elke dag met die bus skool toe.

2 Ons word gebruik om te wys dat iets aan die spreker en aan een of meer ander persone behoort. $\Rightarrow$ Ek hoop nie hulle het al ons [our] lekkers opgeëet terwyl ons weg was nie.

NWSG is daarop gerig om sy teikengebruikergroep te help met die lees en verstaan, maar ook die produksie van Afrikaanse tekste. Uit gesprekke met die uitgewer asook met skrywers van handboeke vir die betrokke leerdergroep kon die inskrywingstipes waaraan die betrokke teikengebruikers behoefte het ten einde die vasgestelde leksikografiese funksies te bevredig, geïdentifiseer word. Hierdie datatipes is betekenisparafrases, grammatiese leiding, veral met betrekking tot morfologie, gebruiksvoorbeelde en gebruiksaantekeninge. Gevolglik het die dataverspreidingstruktuur voorsiening gemaak vir die insluiting van inskrywings uit die tersaaklike datatipes. Die fokus was egter nie net op die sentrale teks van die woordeboek nie, maar voorsiening is ook gemaak vir die totstandbrenging van 'n raamstruktuur (vgl. Kammerer en Wiegand 1998, en Gouws 2001; 2004a), met die voortekste-afdeling wat onder meer 'n gebruiksleidingsteks insluit en die agtertekste-afdeling wat die kennisgerigte funksie van die woordeboek ondersteun deur die insluiting van lyste van die Suid-Afrikaanse provinsies en hulle hoofstede, die amptelike tale van SuidAfrika en die name van die maande van die jaar en die dae van die week. Die woordeboek word 'n politoeganklike bron deurdat die agtertekste-afdeling as buiteteks 'n alfabetiese ekwivalentregister bevat met al die Engelse ekwivalente wat in die sentrale teks se voorbeelde verstrek is. Hierdie ekwivalente word telkens van 'n Afrikaanse inskrywing of inskrywings voorsien wat die gebruiker lei na die lemma van die artikel waarin die betrokke vertaalekwivalent optree. Vergelyk die volgende gedeeltelike artikeltrajek uit die ekwivalentregister:

junk; gemors

just; juis, sommer

justify; regverdig

Uit die gebruikersprofiel wat vir hierdie woordeboek vasgestel is, het geblyk dat die beplande teikengebruikers nie vertroud is met 'n woordeboekkultuur nie en dat baie van die onderwysers wat hulle behulpsaam moet wees in die tipiese gebruiksituasie nie in ' $n$ posisie is om hulle te help met 'n optimale ontsluiting van die inligting in die woordeboek nie. Hierdie realiteit strook met Carstens (1995) se bevindinge. Die woordeboekstrukture van NWSG moes sodanig wees dat die teikengebruiker daartoe in staat sou wees om 'n suksesvolle woordeboeknaslaanhandeling te kan uitvoer sonder deurlopende bystand; ook omdat die gebruiksituasie sodanig sou wees dat die woordeboek nie altyd in 'n klaskamer gebruik word nie, maar ook tuis waar die gebruiker nie noodwen- 
dig op ander hulp aangewese kan wees nie. Gevolglik moes die struktuur eenvoudig en doeltreffend wees. Dit het gelei tot die keuse van 'n streng alfabetiese makrostruktuur wat slegs uit hooflemmata bestaan en geen nes- of nislemmatisering vertoon nie. Dit het 'n geïntegreerde mikrostruktuur waar voorbeeldsinne in die onderskeie semantiese subkommentare telkens onmiddellik op die betekenisparafrases volg en waar prosedures van regstreekse lemmatiese en nielemmatiese adressering geld. Die behoefte aan gebruiksaantekeninge het die leksikograwe genoodsaak om 'n heterogene artikelstruktuur in te voer wat naas die verstekartikelstruktuur ook vir 'n meer komplekse uitgebreide verpligte mikrostruktuur voorsiening gemaak het. Gebruiksaantekeninge is gevolglik in tekskassies in spesiale artikelgleuwe geplaas. Twee tipes tekskassies word onderskei, te wete een wat gemerk is met 'n tekening van 'n by en een wat gemerk is met 'n tekening van 'n skilpad. Die by waarsku leerders teen tipiese foute terwyl die skilpad bykomende inligting, veral oor die leksikale item wat deur die lemmateken voorgestel word, verstrek. Vergelyk die volgende voorbeeldartikels in hierdie verband:

\begin{tabular}{|c|c|}
\hline \multicolumn{2}{|c|}{$\begin{array}{l}\text { grootte naamwoord } \\
\text { Die grootte van iets is hoe groot dit is. } \\
\Rightarrow \text { Wat is die grootte [size] van jou skoene? } \\
\Rightarrow \text { Sy weet nie wat die grootte [size] van die } \\
\text { swembad is nie. }\end{array}$} \\
\hline grootte & $\begin{array}{l}\text { Pasop vir grootte en } \\
\text { grote. } \\
\Rightarrow \text { Daardie vis is 'n grote } \\
\text { [big one]. } \Rightarrow \text { Watter } \\
\text { ek dra jy? }\end{array}$ \\
\hline $\begin{array}{l}\text { haar }^{2} \\
\text { (hare, } \\
\text { 'n Haar } \\
\text { sommi } \\
\text { assebli } \\
\text { gaan. }\end{array}$ & $\begin{array}{l}\qquad \text { naamwoord } \\
\text { ng wat uit mense en } \\
\text { velle groei. } \Rightarrow \text { Borsel } \\
\text { [hair] voordat jy skool toe } \\
\text { erloor baie hare [hair]. }\end{array}$ \\
\hline dit wil & $\begin{array}{l}\text { Haar word meestal in } \\
\text { die meervoud gebruik, } \\
\text { ie meisie het pragtige, }\end{array}$ \\
\hline
\end{tabular}

Wiegand (1989a: 427) onderskei twee belangrike kategorieë funksionele tekssegmente op mikrostrukturele vlak, te wete aanduiders en struktuurmerkers. 
Aanduiders is funksionele tekssegmente waaruit die gebruiker inligting oor die voorwerp waarop die woordeboek gerig is of oor die vorm van die woordeboek kan bekom. Daarteenoor is struktuurmerkers inskrywings wat die gebruiker help om aanduiders beter te identifiseer, te onderskei en sistematies en vinnig te vind. Vir die teikengebruiker van NWSG is die toegangstruktuur en die soekgebiedstruktuur van groot belang. Struktuurmerkers help met die soekroete na die verskillende aanduiders waaraan gebruikers die tersaaklike inligting kan onttrek om sowel teksresepsie as teksproduksie moontlik te maak. Duidelik onderskeibare soekvelde in artikels wat 'n mikro-argitektuur vertoon, is nodig om die sukses van die kennis- en die kommunikasiegerigte funksies te verseker. Die volgende artikel het onder meer 'n kennisgerigte funksie, soos blyk uit die betekenisparafrase asook die ingevoegde teks in die tekskassie:

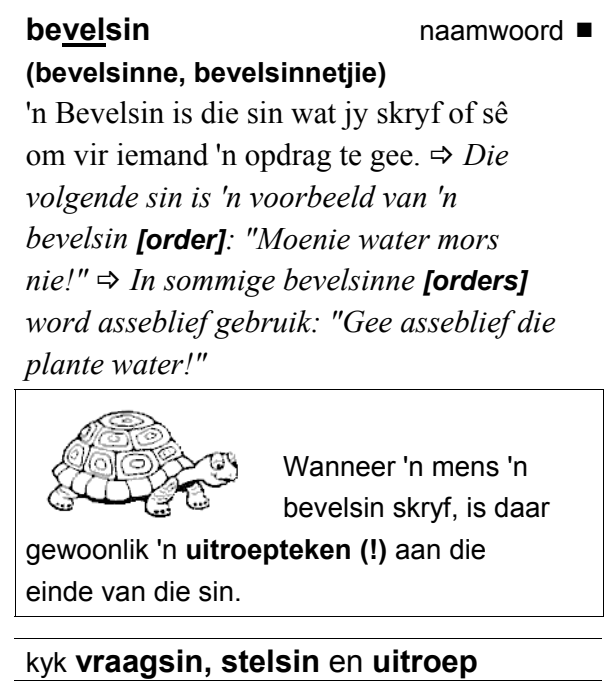

Die volgende artikels het sterker kommunikasiegerigte funksies:
uithaal
werkwoord
(het uitgehaal)
( As 'n mens iets uithaal, bring jy dit buitentoe. $\Rightarrow$ Haal asseblief die suiker uit [take out] die kas. $\Rightarrow$ Die onderwyser raas elke dag met Vuyo omdat hy nie sy hande uit sy sakke haal [take out] nie.
2 As 'n mens baie hard probeer, dan haal jy uit. $\Rightarrow$ Ons sal vandag moet uithaal [exert ourselves] om die span te klop. $\Rightarrow$ As julle nie alles uithaal [exert yourselves] nie, sal julle nie slaag nie. 


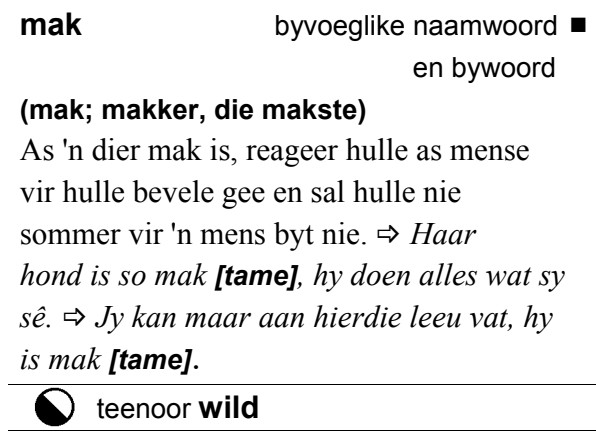

Weens die teikengebruiker se onvertroudheid met woordeboeke is daar besluit op duidelik onderskeibare soekvelde met eksplisiete tipografiese en/of nietipografiese struktuurmerkers, selfs in die geval van soekvelde wat die betekenisparafrase en voorbeeldmateriaal bevat.

Alhoewel die aanduiders wat in NWSG die data-items weergee, nie afwyk van dié wat in talle ander woordeboeke gevind word nie, speel die struktuurmerkers ' $n$ belangrike rol om veral die interne toegangstruktuur te verbeter en 'n gebruikersvriendelike soekroete te bewerkstellig. Dit is in regstreekse reaksie op die behoeftes van die gebruikers. Die mikrostrukturele inhoud en die woordeboekstrukture tree saam op om die gewenste leksikografiese funksies te vervul.

\section{Ten slotte}

Die aard en omvang van die leksikografiese proses van enige woordeboek mag nooit onderskat word nie. In hierdie proses moet daar voorsiening gemaak word vir ' $n$ verskeidenheid fases en aspekte en moet daar gelet word op ' $n$ aktiewe wisselwerking tussen verskillende komponente van die beplande woordeboek, maar ook 'n interafhanklikheid wat tussen sommige van hierdie komponente bestaan. Waar die vroeë leksikografiese navorsing sterk gefokus het op die inhoud van woordeboeke, die latere navorsing op woordeboekstrukture en onlangse navorsing op leksikografiese funksies, moet die hedendaadgse leksikograaf aan al drie hierdie komponente aandag gee in die beplanning en opstelling van ' $n$ woordeboek. Vanuit 'n gebruikersgedrewe benadering is dit noodsaaklik om reeds vroeg te besluit watter leksikografiese funksies die woordeboek moet vervul. Die datakeuse moet in ooreenstemming hiermee gedoen word en daar moet op woordeboekstrukture en hulle aard besluit word waarin die data op ' $n$ sodanige manier aangebied kan word dat dit die teikengebruiker in staat stel om 'n optimale inligtingsonttrekking te verwesenlik. Om dit moontlik te maak, is die dataverspreidingstruktuur en die totstandbrenging van ' $n$ soekgebiedstruktuur en 'n mikro-argitektuur binne die woordeboekartikels van deurslaggewende belang. 


\section{Bibliografie}

Bergenholtz, H. en S. Tarp. 2002. Die moderne lexikographische Funktionslehre. Diskussionsbeitrag zu neuen und alten Paradigmen, die Wörterbücher als Gebrauchsgegenstände verstehen. Lexicographica 18: 253-263.

Carstens, A. 1995. Language Teaching and Dictionary Use: An Overview. Lexikos 5: 105-116.

Dolezal, F. 1986. How Abstract is the English Dictionary? Hartmann, R.R.K. (Red.). 1986. The History of Lexicography: 47-55. Amsterdam: John Benjamins.

Gouws, R.H. 2001. Der Einfluß der neueren Wörterbuchforschung auf einen lexikographischen Gesamtprozeß und den lexikographischen Herstellungsprozeß. Lehr, A. et al. (Reds.). Sprache im Alltag: 521-531. Berlyn: De Gruyter.

Gouws, R.H. 2004. Milestones in Metalexicography. Van Sterkenburg, P.G.J. (Red.). 2004. Linguistics Today — Facing a Greater Challenge: 187- 205. Amsterdam: John Benjamins.

Gouws, R.H. 2004a. Outer Texts in Bilingual Dictionaries. Lexikos 14: 67-88.

Gouws, R.H. en D.J. Prinsloo. 2005. Principles and Practice of South African Lexicography. Stellenbosch: African Sun Media.

Gouws, R.H., M. Stark en L. Gouws. 2004. Nuwe Woordeboek sonder Grense. Kaapstad: Maskew Miller Longman.

Hartmann, R.R.K. en G. James. 1998. Dictionary of Lexicography. Londen: Routledge.

Hausmann, F.J. 1977. Einführung in die Benutzung des neufranzösischen Wörterbücher. Romanistische Arbeitshefte 19. Tübingen: Max Niemeyer.

Hausmann, F.J. en H.E. Wiegand. 1989. Component Parts and Structures of General Monolingual Dictionaries: A Survey. Hausmann, F.J. et al. (Reds.). 1989-1991: 328-360.

Hausmann, F.J. et al. (Reds.). 1989-1991: Wörterbücher. Ein internationales Handbuch zur Lexikographie/Dictionaries. An International Encyclopedia of Lexicography/Dictionnaires. Encyclopédie internationale de lexicographie. Handbücher zur Sprach- und Kommunikationswissenschaft 5.1-5.3. Berlyn/New York: Walter de Gruyter.

Kammerer, M. en H.E. Wiegand. 1998. Über die textuelle Rahmenstruktur von Printwörterbüchern: Präzisierungen und weiterführende Überlegungen. Lexicographica 14: 224-237.

Kromann, H.-P., T. Riiber, P. Rosbach. 1984. Überlegungen zu Grundfragen der zweisprachigen Lexikographie. Wiegand, H.E. (Red.). Studien zur neuhochdeutschen Lexikographie: 159-238. Hildesheim: Georg Olms Verlag.

Louw, P.A. 1997. Kriteria vir 'n standaard vertalende woordeboek. Ongepubliseerde MA-skripsie. Stellenbosch: Universiteit van Stellenbosch.

Mihindou, G.-R. In voorbereiding. A Theoretical Model for a Yipunu-English-French Explanatory Dictionary of Medical Terms. Ongepubliseerde D.Litt.-verhandeling. Stellenbosch: Universiteit van Stellenbosch.

Nielsen, S. 2003. Changes in Dictionary Subject Matter. Wiegand, H.E. (Red.). 2003. Untersuchungen zur kommerziellen Lexikographie der deutschen Gegenwartssprache I: 109-114. Tübingen: Max Niemeyer Verlag.

Ščerba, L.V. 1940. Towards a General Theory of Lexicography. International Journal of Lexicography 8 (4): 315-350, 1995

Steyn, M. en L. Gouws. 2005. Nuwe Woordeboek sonder Grense: A Typological and Communicative Bridge. Lexikos 15: 164-178. 
Swanepoel, P. 2001. Dictionary Quality and Dictionary Design: A Methodology for Improving the Functional Quality of Dictionaries. Lexikos 11: 160-190.

Tarp, S. 2000. Theoretical Challenges to LSP Lexicography. Lexikos 10: 189-208.

Tarp, S. 2004. Basic Problems of Learner's Lexicography. Lexikos 14: 222-252.

Tarp, S. en R.H. Gouws. 2004. Wie leer wat uit Afrikaanse (aan)leerderwoordeboeke. Tydskrif vir Geesteswetenskappe 44(4): 276-298.

Wiegand, H.E. 1989. Der gegenwärtige Status der Lexikographie. Hausmann, F.J. et al. (Reds.). 1989-1991: 246-280.

Wiegand, H.E. 1989a. Der Begriff der Mikrostruktur: Geschichte, Probleme, Perspektiven. Hausmann, F.J. et al. (Reds.). 1989-1991: 409-462.

Wiegand, H.E. 1989b. Aspekte der Makrostruktur im allgemeinen einsprachigen Wörterbuch: Alphabetische Anordnungsformen und ihre Probleme. Hausmann, F.J. et al. (Reds.). 1989-1991: 371-409.

Wiegand, H.E. 1989c. Arten von Mikrostrukturen im allgemeinen einsprachigen Wörterbuch. Hausmann, F.J. et al. (Reds.). 1989-1991: 462-501.

Wiegand, H.E. 1996. Das Konzept der semiintegrierten Mikrostrukturen. Ein Beitrag zur Theorie zweisprachiger Printwörterbücher. Wiegand, H.E. (Red.). Wörterbücher in der Diskussion II. 1989-1991: 1-82. Tübingen: Max Niemeyer Verlag.

Wiegand, H.E. 1998. Wörterbuchforschung. Berlyn: De Gruyter.

Zgusta, L. 1971. Manual of Lexicography. Den Haag: Mouton. 